\title{
Cellulitis in a Red Kandhari Bull : A Case Report
}

\author{
MM Pathan, MA Khan, AV Bhonsle, AU Bhikane, SD Moregaonkar, MB Kulkarni \\ Department of Pathology, \\ College of Veterinary and Animal Sciences, Maharashtra Animal and Fishery Science University, \\ Udgir, Dist. Latur, Maharashtra, India \\ * Corresponding author email: muqtark@gmail.com \\ Received: 20-08-2011, Accepted: 29-08-2011, Published Online: 12-12-2011 \\ doi: $10.5455 /$ vetworld.2012.183-184
}

\begin{abstract}
A case of cellulitis caused by mixed infection of Staphylococcus spp. and Corynebacterium spp in a Red Kandhari bull leading to death of animal was autopsied at the department. It is being a case of cellulitis in a Red Kandhari bull and placed on record.

Keywords: Cellulitis, Bull, Necropsy findings, Connective tissue, Inflammation.

\section{To cite this article :}

Pathan MM, Khan MA, Bhonsle AV, Bhikane AU, Moregaonkar SD, Kulkarni MB (2012) Cellulitis in a Red Kandhari Bull : A Case Report, Vet. World. 5(3): 183-184, doi: 10.5455/vetworld.2012.183-184.
\end{abstract}

Cellulitis is diffusely spreading suppurative inflammation of connective tissue having red margins and caused by mixed infection of Streptococci spp, Staphylococcus spp. and Corynebacterium spp. (Shastry and Rao, 2006).

Cellulitis is common in poultry birds and not in other domestic animals. It is rarely reported in livestock.

\section{Case History, Clinical Findings}

A Red Kandhari bull was presented to the Teaching Veterinary Clinical Complex, College of Veterinary and Animal Sciences, Udgir, with the history of anorexia, tympany, and swelling on right side of neck.

Clinical Examination of particular bull revealed that there was a painful muscular swelling on neck making animal unable to keep the neck in straight position. There was high temperature $\left(105^{\circ} \mathrm{F}\right)$, elevated pulse rate $(82 / \mathrm{min})$ and increased respiratory rate with tympany. The visible mucous membranes were congested; skin and hair coat was dry and rough. The calf was passing scanty semisolid faeces and pale yellow coloured urine.

Microbiological Findings: The material collected from the affected tissue of the carcass was subjected to the microbiological investigation. The isolation and identification of bacteria based on the microscopic examination, cultural and biochemical characteristics revealed the isolates as Staphylococcus spp. and Corynebacterium spp.

\section{Treatment}

The bull was treated with antibiotic Inj. QuinIntas (Enrofloxacin-100 mg) @ $15 \mathrm{ml} \mathrm{I} / \mathrm{M}$ (Intas Pharmaceuticals Ltd. Ahmedabad) and supportive therapy in the form of Inj. Dextrose 5\%@ 2 lit. /day I/M (Fresenius Kabi India pvt. Ltd. Pune) and Inj. RL (Compoud Sodium Lactate Injection) @ ml I/M (Fresenius Kabi India pvt. Ltd. Pune), alternatively along with Inj. Tribivet (Vit. B1-B6-B12) @ $5 \mathrm{ml}$ //M (Intas Pharmaceuticals Ltd. Ahmedabad), despite the treatment bull died on $6^{\text {th }}$ day.

\section{Necropsy Findings}

The carcass of Red Kandhari bull died at Teaching Veterinary Clinical Complex was presented to the Department of Pathology for necropsy examination. The carcass was subjected to detailed necropsy examination and the findings were recorded as follows: 
External Findings: On external examination the bull was emaciated and bloated with severe inflammation on right side of neck. Mass of muscle like swelling was present on the neck.

Internal Findings: After removal of hide, gangrenous myositis was observed at the place of swelling on the neck. The area was dark brown with fragile mass giving shaggy appearance and foul odour.

Lungs were emphysematous with patches of pneumonia. Pericardium was thickened and there were current jelly clots in the chambers of the heart. Liver was hypertrophied with foci of necrosis on it. Liver capsule was thickened and inflamed. Gall bladder was distended with yellowish discolouration of abdominal organs (bile imbibition). Kidneys were markedly lobulated; on section kidneys appeared pale with focal necrotic areas on them.

\section{Result and Discussion}

Considering clinical history, gross lesions, autopsy findings and microbiological isolations, the cause of death in this case appeared to be Cellulitis leading to septicaemia, toxaemia and septic shock.

Microbiological examinations have confirmed the cause as Staphylococcus spp. and Corynebacterium spp. mixed infection leading to cellulitis. Sonia, et al., (2008) have reported generalized, severe cellulitis caused by Streptococcus dysgalactiae sub sp. dysgalactiae in an adult Brown Swiss cow, which died rapidly and another case of cellulitis in thorax and abdominal region in three cows reported by Braun et al., (2005) supports the findings of present case.

\section{References}

1. Braun U., Bleul U., Schweizer G. and Nuss K. (2005). Ultrasonographic findings in three cows with cellulitis. Veterinary Record. 157, p. 26-28.

2. Shastri, G. A. and Ramarao, P. (2006). Veterinary Pathology. $7^{\text {th }}$ Edn., CBS Publishers \& Distributors. p. 61.

3. Sonia Chénier, Mathilde Leclère, Serge Messier and Gilles Fecteau. (2008). Streptococcus dysgalactiae cellulitis and toxic shock like syndrome in a Brown Swiss cow. Journal of Veterinary Diagnostic Investigation. 20 (1), p. 99-103. 